\title{
Muş İlindeki Besi İşletmelerinde Memnuniyet ve Etkileyen Faktörler
}

Galip BAKIR ${ }^{1}$ Mustafa KIBARR ${ }^{2}$

${ }^{1}$ Kahramanmaraş Sütçüimam Üniversitesi, Ziraat Fakültesi Zootekni Bölümü, Kahramanmaraş, ${ }^{2}$ Siirt Üniversitesi, Ziraat Fakültesi Zootekni Bölümü Siirt, Türkiye

${ }^{1}$ https://orcid.org/0000-0002-0816-227X, ${ }^{2}$ https://orcid.org/0000 $00021895019 \mathrm{X}$

$\bowtie$ : galipbakir@hotmail.com

\section{ÖZET}

$\mathrm{Bu}$ araştırmada, besi işletmecilerinin memnuniyet düzeyleri ve etkileyen faktörleri belirlemek amacıyla Muş İli ve 5 ilçesinde 368 işletme sahibiyle yüz yüze anket çalışması yapılmıştır. Elde edilen veriler SPSS paket programında analiz edilerek, çapraz tablolar oluşturulmuştur. İl genelinde işletmecilerin \%65'inin besicilikten memnun iken, \%35'inin besicilikten memnun olmadıkları belirlenmiştir. İlçeler arasında en yüksek memnuniyet oranları Korkut (\%74.5) ve Varto (\%78.3) ilçelerinde iken en yüksek memnuniyetsizlik oranları ise (\%56.3) Hasköy ilçesinde bulunan işletmelerde belirlenmiştir. Besicilikten memnun olanların \%33.1'i 41-50 yaş grubunda, \%29.2'si $51+$ yaş gurubunda ve \%15.7'si $30 \leq$ yaş grubunda olan genç ve hayvancıllğga yeni başlayan işletmecilerde bulunmuştur. Birey sayısı $4 \leq$ olan işletmecilerin en yüksek memnuniyet oranına sahip oldukları ve birey sayısı arttıkça memnuniyet oranının azalması anlamlı bulunmuştur. Hayvan sayısı $5 \leq$ olan işletmelerde besicilikten memnuniyet oranı \%63.5 iken, hayvan sayısı arttıkça (21-40 baş) memnuniyet oranı \%72.9'a yükselmiştir. Irklar içerisinde işletmecilerin en yüksek (\%67) memnuniyet oranı melez ırkında bulunurken, bunu kültür ırkı izlemiştir. Besiciliğin yanında başka bir iş yapan işletmecilerin, \%70.7 oranıyla sadece besicilik yapanlara göre daha memnun oldukları belirlenmiştir. Besi sonunda hayvanlarını eder fiyata satan işletmecilerin \%74.7'sinin besicilikten memnun oldukları belirlenmiştir. Besi sonunda hayvanlarını eder fiyata satsalar bile işletmecilerin \%25.3'ünün besicilikten memnun olmadıkları tespit edilmiştir. Besicilikten memnun olan işletmecilerin tamamına yakını (\%97.4) ve memnun olmayan işletmecilerin \%68.3’ünün besiciliği sürdürmek istedikleri belirlenmiştir.

\section{Araştırma Makalesi}

Makale Tarihçesi
Geliş Tarihi $\quad: 08.04 .2020$
Kabul Tarihi $\quad: 30.06 .2020$

Anahtar Kelimeler
Memnuniyet
Etkileyen faktörler
Besi işletmesi
Muş

Research Article

$\begin{array}{ll}\text { Article History } & \\ \text { Received } & : 08.04 .2020 \\ \text { Accepted } & : 30.06 .2020\end{array}$

Keywords

Satisfaction

Factors affecting

Fattening farms

Muş Province 
rate was highest (67\%) for the farmers having crossbred animals followed by pure culture bred ones. Farmers who are performing other business besides fattening were more satisfied (70.7\%) than those who are doing just fattening. At the end of fattening, $74.7 \%$ of the farmers who sold their animals at an appropriate price were found to be satisfied with fattening. Overall, $25.3 \%$ of the farmers were dissatisfied with beef cattle even they sold their animals at an appropriate price at the end of fattening. It was determined that nearly all $(97.4 \%)$ of the farmers who were satisfied with the beef cattle and $68.3 \%$ of the dissatisfied ones wanted to maintain the beef fattening farming.

\begin{tabular}{ll}
\hline Atıf İçin: & Bakır G, Kibar M 2021. Muş İlindeki Besi İşletmelerinde Memnuniyet ve Etkileyen Faktörler. KSÜ Tarım ve \\
& Doğa Derg 24 (1): 231-241. https://doi.org/10.18016/ksutarimdoga.vi.716591. \\
To Cite: & Bakır G, Kibar M 2021. Satisfaction and Affecting Factors in Fattening Farms in Muş Province. KSU J. Agric \\
& Nat 24 (1): 231-241. https://doi.org/10.18016/ksutarimdoga.vi.716591. \\
\hline
\end{tabular}

\section{GİRIŞ}

Besi sığırcılığı, artan Dünya nüfusunun besin madde ihtiyaçlarının karşılanması için önemli bir tarımsal faaliyettir. Bununla birlikte, ülkelerin gelişmişlik düzeyi göstergelerinden kabul edilen kişi başına düşen kırmızı et tüketim miktarının yükselmesinde de önemlidir. Besi sığırcılığı ile üretilen kırmızı etin besin değerinin yüksek olması nedeniyle insanların beyin güçlerinin artması sağlanmaktadır. Bu sayede de kırmızı et tüketimi o ülkenin insanlarının daha çok üretmesine katkı sağlar ve gelişmişlik seviyesinin yükselmesine yardımcı olur şeklinde açıklanabilmektedir. Çünkü Dünya'ca kabul görmüş olan fenotipin genotip ve çevrenin etkisi altında olması kuralı da bu durumu destekler niteliktedir. Yani et tüketen bir ülke ile ekmek tüketen bir ülkenin üreteceği her şey de tükettiği ürünün bir parçası bulunacaktır. Kişi başına düşen kırmızı et tüketimini yükseltmek için de besi sığırcılığının diğer tüm mesleklerde olduğu gibi sevilerek yapılması gerekmektedir.

Besiciliğin bir ülkede gelişme göstermesi, ekonomik değer üretmesinin yanı sıra insanlara iş imkânı sunması ve mevcut insanların ve gelecek nesillerin sağlıklı yetişmesine de önemli katkı sağlamaktadır. $\mathrm{Bu}$ nedenle işletmelerin sürdürülebilirliği hayati önem arz ederken, işletmelerin sürdürülebilirliği işletmecilerin memnuniyeti ile doğrudan ilişkili oluğu bilinmektedir.

Başarı ancak bir mesleğin sevilerek yapılması ile mümkündür. $\mathrm{Bu}$ nedenle de hem ülke ekonomisine katkı sağlamak, hem de toplumsal refahın artması için besi işletmecilerinin yaptığı işten memnun olması önem arz etmektedir. Yetiştiricilerin yaptığ ${ }_{1}$ her uygulamadan hem ülke ekonomisi, hem kendisi hem de o üretilen ürünleri tüketen her birey etkilenmektedir. Besicilerin memnuniyet düzeylerinin ve etkileyen faktörlerin belirlenmesinde ise anket şu ana kadar en temel araştırma metodu olmuştur. Besi işletmelerinde memnuniyet ve sürdürülebilirlikle ilgili yapılan çalışma sayısı çok azdır.
Hayvancılık işletmelerinde, işletmelerin yapısal özelliklerine yönelik birçok araştırma bulunmaktadır. Yapılan memnuniyet çalışmaları da daha çok tüketicilere yöneliktir (Muldano ve Thieme, 2009; Kwadzo ve ark. 2013; İnci ve ark., 2014; Karakaya ve İnci, 2014). Hayvancılık alanında işletmecilerin yaptıkları işten memnuniyetlerine yönelik çok az araştırma (Özen ve Oluğ, 1996; Soyak ve ark., 2007; Han, 2008; Mohanraj and Manivannan 2012; Can ve Yalçın, 2015; Ünalan ve ark., 2015; Koçyiğit ve ark.,2016; Koçyiğit ve ark., 2018; Tümer ve ark., 2018; Bakır ve Kibar, 2019a,b) olduğu belirlenmiştir. Bu araştırma literatürde önemli bir açığı kapatacak olması yönüyle önemini ortaya koymaktadır. Bu çalışmanın amacı, Muş ili besi sığırcılığı işletmelerinde, işletmecilerin yaptıkları işten memnuniyet durumlarının ve işletmecilerin memnuniyetine etkili olan faktörlerin belirlenmesidir.

\section{MATERYAL ve METOT}

Araştırma materyalini, Muş ili merkez ve ilçelerinde (Malazgirt, Bulanık, Hasköy, Korkut ve Varto) bulunan büyükbaş besi işletmelerinde yüz yüze yapılan anket verileri oluşturmuştur. Araştırmada, büyükbaş hayvan varlığı bakımından ilçeleri temsil eden köyler, bölgede görev yapan il müdürlüğünde çalışan mühendis ve veteriner hekimlerin görüşü alınarak belirlenmiştir. Anket soruları yazarlar tarafından geniş bir literatür taraması neticesinde hazırlanmış olup, daha sonra konu uzmanları ile yapılan görüşmeler ile son şeklini almıştır. Muş yöresine kayıtlı büyükbaş hayvancılık işletmelerinden besi yapanlara ait 2017 yılinda anket yolu ile veriler toplanmıştır. İşletmelerde simental, siyah alaca, esmer gibi kültür ırkları ile bunların yerli ırklarla oluşan melez ırklar yetiştirilmektedir. Muş İl Tarım ve Orman Müdürlüğü kayıtlarından alınan toplam işletme sayısı dikkate alınarak, 368 (\%6.2) işletme şansa bağlı olarak belirlenmiştir. İşletme sayısının belirlenmesinde örnek hacminin en az \%3’ünün (Yamane, 2006) veya en çok örnek hacminin \%10'unun 
(Cochran, 1977; Arıkan, 2000) alınmasının yeterli olacağ 1 ilkesi dikkate alınmıştır. Ankete katılan işletmeciler bazı sorulara cevap vermediği için bazı çizelgelerde toplam anket sayısı değişiklik göstermiştir. Verilerin analizinde SPSS 21.0 paket programı kullanılarak, satır ve sütun yönlü çapraz tablolar (row/column crosstabs) oluşturulmuştur. Buna göre, tabloların yorumu hem satırdaki hem de sütundaki parametrelere göre yorumlanacaktır. İlçeler arasındaki farklılıkların belirlenmesi için kikare önemlilik testi (Düzgüneş ve ark., 1983) yapılmış ve bazı özelliklere ait ortalama, maksimum ve minimum frekans değerleri verilmiştir.

\section{BULGULAR VE TARTIŞMA}

Il genelinde işletmelerin \%65'inin besicilikten memnun iken, \%35'inin besicilikten memnun olmadıkları belirlenmiştir. Besicilikten en çok memnun olan işletmelerin Korkut (\%78.3) ve Varto (\%74.5) ilçelerinde ve buna karşın en çok memnun olmayan işletmelerin ise Hasköy (\%56.3) ilçesinde bulunduğu belirlenmiştir (Çizelge 1). İşletmecilerin besicilikten memnuniyeti ile mevki arasında önemli $(\mathrm{p}<0.01)$ farklılıklar bulunmuştur.

Bakır ve Kibar, (2019a) tarafından Muş ilinde süt işletmelerinde yapılan çalışmada memnuniyet düzeylerinin mevkilere göre önemli farklılıklar gösterdiği belirlenmiştir. Genel olarak süt sığırı işletmelerinde işletmecilerin memnuniyet oranı (\%64) ile besicilik işletmelerinde bulunan memnuniyet oranı (\%65) yakın bulunmuştur. İlçeler bazında bakıldığında, süt ve besi sığırcıllğından memnun olan ve olmayanların oranları benzerlik göstermiştir. İlçeler arasındaki farklılık böyle çalışmaların daha ayrıntılı olarak yapılmasının gerektiğini işaret etmektedir. Araştırmacıların Siirt ilinde yaptıkları diğer araştırmada ise, besicilikten memnun olanların oranı \%59.8 olarak belirlenmiştir. Bu değer mevcut çalışmadan düşük bulunmuştur. Siirt ilinde ilçeler arasındaki farklılıklar önemli çıkmış olup, en çok memnuniyet Pervari ilçesinde iken, en çok memnuniyetsizlik Merkez ilçede belirlenmiştir (Bakır ve Kibar, 2019b). Tutkun ve ark. (2017) Diyarbakır ilindeki tüm ilçelerde bulunan 192 sığır işletmesinde yaptığ 1 ankette işletmecilerin \%86'sının memnun olmadıklarını belirtmişler ve bu oran mevcut çalışmadan (\%35) çok yüksek bulunmuştur. Han (2008) Diyarbakır Ergani ilçesindeki 167 sığır işletmesinde yaptığı araştırmada besi işletmecilerinin \%64.7'sinin memnun olduğunu belirtmiş ve bu oran mevcut çalışma ile büyük benzerlik göstermiştir.

Çizelge 1. İşletmelerde memnuniyetin mevkiye göre değişimi

Table 1. Change of satisfaction by location of farmers

\begin{tabular}{|c|c|c|c|c|c|c|c|c|}
\hline \multirow{2}{*}{\multicolumn{2}{|c|}{$\begin{array}{l}\text { Memnuniyet } \\
\text { (Satisfaction) }\end{array}$}} & \multicolumn{6}{|c|}{ Mevki** (Location) } & \multirow{2}{*}{$\begin{array}{l}\text { Toplam } \\
\text { (Total) }\end{array}$} \\
\hline & & Merkez & Malazgirt & Bulanık & Hasköy & Korkut & Varto & \\
\hline \multirow{3}{*}{$\begin{array}{l}\text { Evet } \\
\text { (Yes) }\end{array}$} & Adet & 36 & 39 & 61 & 7 & 54 & 41 & 238 \\
\hline & $\%$ Memnuniyet & 15.1 & 16.4 & 25.6 & 2.9 & 22.7 & 17.2 & 100.0 \\
\hline & $\%$ Mevki & 60.0 & 51.3 & 67.8 & 43.8 & 78.3 & 74.5 & 65.0 \\
\hline \multirow{3}{*}{$\begin{array}{l}\text { Hayır } \\
\text { (No) }\end{array}$} & Adet & 24 & 37 & 29 & 9 & 15 & 14 & 128 \\
\hline & $\%$ Memnuniyet & 18.8 & 28.9 & 22.7 & 7.0 & 11.7 & 10.9 & 100.0 \\
\hline & \% Mevki & 40.0 & 48.7 & 32.2 & 56.3 & 21.7 & 25.5 & 35.0 \\
\hline \multirow{3}{*}{$\begin{array}{l}\text { Toplam } \\
\text { (Total) }\end{array}$} & Adet & 60 & 76 & 90 & 16 & 69 & 55 & 366 \\
\hline & $\%$ Memnuniyet & 16.4 & 20.8 & 24.6 & 4.4 & 18.9 & 15.0 & 100.0 \\
\hline & $\%$ Mevki & 100.0 & 100.0 & 100.0 & 100.0 & 100.0 & 100.0 & 100.0 \\
\hline
\end{tabular}

Besicilikten memnun olanların \%33.1'ini 41-50 yaş grubundaki işletmeciler oluşturmaktadır. Elli bir ve üzeri yaşa sahip işletmecilerde bu oran \%29.2'ye düşerken, 30 ve daha genç olan ve hayvancılığa yeni başlayan işletmecilerde bu oran \%15.7 olarak bulunmuştur. Genç ve yaşlı işletmecilerin besicilikten memnuniyet oranlarının düşük olması, genç işletmecilerin tecrübesizliği ve işe olan hâkimiyetlerinin yetersiz olmasından, yaşlı işletmecilerin ise besicilikten beklentilerinin karşılanmasından kaynaklandığı düşünülmektedir. Besicilikten memnuniyet, işletmecilerin yaşına göre değerlendirildiğinde, tüm yaş grubunda memnuniyet oranları birbirlerine yakın bulunmakla birlikte, 30 yaş ve altındaki yetiştiricilerde memnuniyet oranı \%66.1 iken, yaşı 51+ işletmecilerde bu oran \%63.9'a gerilemiştir. Buna göre, genç yetiştiricilerin yaşlılardan besicilikten daha memnun oldukları söylenebilir (Çizelge 2). Besicilikten memnuniyete işletmecilerin hayvancılık yaptıkları süreye göre bakıldığında, en yüksek memnuniyet oranı (\%70) 2130 yıl aralığındaki işletmecilerde bulunmuştur. Hayvancılık yapılan süre 10 yıldan az olan ve bunların çoğunluğu genç işletmecilerden oluşan grupta memnuniyet oranı \%63.1 iken, hayvancllık yapılan süre 31 ve üzeri olan ve bunların tamamı yaşh işletmecilerden oluşanlarda ise hafif bir düşüşle memnuniyet oranı \%62.9'a gerilemiştir (Çizelge 2). 
Cizelge 2. Memnuniyetin işletmecilerin yaşı ve hayvancılık yapılan süreye göre değişimi

Table 2. Change of satisfaction according to the age of the farmers and the duration of animal husbandry

\begin{tabular}{|c|c|c|c|c|c|c|c|c|c|c|c|}
\hline \multirow{2}{*}{\multicolumn{2}{|c|}{$\begin{array}{l}\text { Memnuniyet } \\
\text { (Satisfaction) }\end{array}$}} & \multicolumn{4}{|c|}{ Yaş (Age) } & \multirow{2}{*}{$\begin{array}{r}\text { Toplam } \\
\text { (Total) }\end{array}$} & \multicolumn{4}{|c|}{ Süre (Duration) } & \multirow{2}{*}{$\begin{array}{r}\text { Toplam } \\
(\text { Total) }\end{array}$} \\
\hline & & $<30$ & $31-40$ & $41-50$ & $51+$ & & $<10$ & $11-20$ & $21-30$ & $31+$ & \\
\hline \multirow{3}{*}{$\begin{array}{l}\text { Evet } \\
\text { (Yes) }\end{array}$} & Adet & 37 & 53 & 78 & 70 & 238 & 82 & 63 & 49 & 40 & 234 \\
\hline & $\%$ Memnuniyet & 15.5 & 22.3 & 32.8 & 29.4 & 100.0 & 35.0 & 26.9 & 20.9 & 17.1 & 100.0 \\
\hline & \% Yaş/Süre & 66.1 & 66.3 & 66.1 & 64.2 & 65.6 & 63.1 & 65.6 & 70.0 & 63.5 & 65.2 \\
\hline \multirow{3}{*}{$\begin{array}{l}\text { Hayır } \\
(\mathrm{No})\end{array}$} & Adet & 19 & 27 & 40 & 39 & 125 & 48 & 33 & 21 & 23 & 125 \\
\hline & $\%$ Memnuniyet & 15.2 & 21.6 & 32.0 & 31.2 & 100.0 & 38.4 & 26.4 & 16.8 & 18.4 & 100.0 \\
\hline & \% Yaş/Süre & 33.9 & 33.8 & 33.9 & 35.8 & 34.4 & 36.9 & 34.4 & 30.0 & 36.5 & 34.8 \\
\hline \multirow{3}{*}{$\begin{array}{l}\text { Toplam } \\
\text { (Total) }\end{array}$} & Adet & 56 & 80 & 118 & 109 & 363 & 130 & 96 & 70 & 63 & 359 \\
\hline & $\%$ Memnuniyet & 15.4 & 22.0 & 32.5 & 30.0 & 100.0 & 36.2 & 26.7 & 19.5 & 17.5 & 100.0 \\
\hline & \% Yaş/Süre & 100.0 & 100.0 & 100.0 & 100.0 & 100.0 & 100.0 & 100.0 & 100.0 & 100.0 & 100.0 \\
\hline
\end{tabular}

Çizelge 3. Memnuniyetin hanedeki birey sayısı ve işletmecilerin eğitim durumuna göre değişimi

Table 3. Change of satisfaction according to the number of individuals and the educational status of the farmers

\begin{tabular}{|c|c|c|c|c|c|c|c|c|c|c|c|c|}
\hline \multirow{2}{*}{\multicolumn{2}{|c|}{$\begin{array}{l}\text { Memnuniyet } \\
\text { (Satisfaction) }\end{array}$}} & \multicolumn{4}{|c|}{$\begin{array}{c}\text { Birey sayısı* (The num. of } \\
\text { individuals) }\end{array}$} & \multirow{2}{*}{$\begin{array}{l}\text { Toplam } \\
\text { (Total) }\end{array}$} & \multicolumn{5}{|c|}{ Eğitim durumu- (Educational status) } & \multirow{2}{*}{$\begin{array}{c}\text { Toplam } \\
\text { (Total) }\end{array}$} \\
\hline & & $<4$ & $5-6$ & $7-8$ & $9+$ & & $\begin{array}{c}\text { Okuryazar } \\
\text { değil }\end{array}$ & İkokul & Ortaokul & Lise & Üniversite & \\
\hline \multirow{3}{*}{$\begin{array}{l}\text { Evet } \\
\text { (Yes) }\end{array}$} & Adet & 68 & 64 & 71 & 34 & 237 & 7 & 91 & 97 & 29 & 3 & 227 \\
\hline & $\%$ Memnuniyet & 28.7 & 27.0 & 30.0 & 14.3 & 100.0 & 3.1 & 40.1 & 42.7 & 12.8 & 1.3 & 100.0 \\
\hline & $\begin{array}{l}\text { \% Birey } \\
\text { sayısı/Eğitim }\end{array}$ & 77.3 & 63.4 & 65.1 & 53.1 & 65.5 & 63.6 & 66.4 & 66.9 & 58.0 & 50.0 & $65.0 \%$ \\
\hline \multirow{3}{*}{$\begin{array}{l}\text { Hayır } \\
\text { (No) }\end{array}$} & Adet & 20 & 37 & 38 & 30 & 125 & 4 & 46 & 48 & 21 & 3 & 122 \\
\hline & $\%$ Memnuniyet & 16.0 & 29.6 & 30.4 & 24.0 & 100.0 & 3.3 & 37.7 & 39.3 & 17.2 & 2.5 & 100.0 \\
\hline & $\begin{array}{l}\text { \% Birey } \\
\text { sayısı/Eğitim }\end{array}$ & 22.7 & 36.6 & 34.9 & 46.9 & 34.5 & 36.4 & 33.6 & 33.1 & 42.0 & 50.0 & 35.0 \\
\hline \multirow{3}{*}{$\begin{array}{l}\text { Toplam } \\
\text { (Total) }\end{array}$} & Adet & 88 & 101 & 109 & 64 & 362 & 11 & 137 & 145 & 50 & 6 & 349 \\
\hline & $\%$ Memnuniyet & 24.3 & 27.9 & 30.1 & 17.7 & 100.0 & 3.2 & 39.3 & 41.5 & 14.3 & 1.7 & 100.0 \\
\hline & $\begin{array}{l}\text { \% Birey } \\
\text { sayısı/Eğitim }\end{array}$ & 100.0 & 100.0 & 100.0 & 100.0 & 100.0 & 100.0 & 100.0 & 100.0 & 100.0 & 100.0 & 100.0 \\
\hline
\end{tabular}

${ }^{*} \mathrm{p}<0.05$ 
Yaş ile birlikte işletmecilerin besicilikten memnuniyet düzeyleri arasındaki doğru orantı Bakır ve Kibar, (2019a) ve Bakır ve Kibar, (2019b) çalışmaları ile kısmen uyum içerisindedir. Hayvancılık yapılan süre bakımından ise mevcut çalışmanın bulguları ile Bakır ve Kibar (2019a)'nın tespitleri ile uyum içerisinde iken, Bakır ve Kibar (2019b) farklılık göstermiştir. Han (2008)'nın besi işletmelerinde yaptığı çalışmada 8-13 yıl arasında deneyime sahip olan veya 50-80 yaş grubundaki besi işletmecilerinin \%52.4'ünün besicilikten memnun olmadığını belirtmiştir. Diğer yaş ve deneyim gruplarında memnun olanların oranı daha yüksek bulunmuştur. Araştırıcı yaş ve deneyim süresinin besi işletmecilerinin memnuniyetini istatistiki olarak önemli olarak etkileyen faktörler olarak bildirmiştir. Mevcut çalışmada da işletmecilerin yaşının memnuniyet düzeylerini önemli $(p<0.05)$ şekilde etkilediği tespit edilmiştir.

Kişi sayısı 4 ve az olan işletmelerde memnuniyet oranı \%74.4 iken, birey sayısı arttığında (9 ve üzeri) bu oran ciddi bir düşüşle \%52.4'e gerilemiştir (Çizelge 3). Birey sayısı 4 ve az olan işletmecilerin en yüksek memnuniyet oranına sahip oldukları ve işletmelerde birey sayısı arttıkça memnuniyet oranının azalması anlamlı bulunmuştur. İşletmelerde birey sayısı arttıkça, kişi başına düşen hayvan sayısının azaldığı ve buna bağlı olarak gelirinde azalmasıyla birlikte memnuniyetin azaldığı düşünülmektedir. Ayrıca, birey sayısı 9 ve üzeri olan işletmelerde memnuniyetsizlik oranı diğer gruplara göre en yüksek olup, \%47.6 olarak tespit edilmiştir.

Okuryazar olmayan işletmecilerin \%77.3’ü besicilikten memnun iken, eğitim seviyesi lise olan işletmecilerde memnuniyet oranı \%53.1'e gerilemiştir (Çizelge 3). Buna göre, eğitim seviyesi yükseldikçe memnuniyet oranının düştüğü tespit edilmiştir. Eğitim seviyesi yüksek işletmecilerin genel olarak, genç ve besiciliğe yeni başlayanlar olduğu göz önüne alındığında, bu durum doğal olarak kabul edilebilir. Han (2008) okuryazar işletmecilerin \%66.7'sinin besicilikten memnun olmadığını ve eğitim durumunun memnuniyeti etkileyen önemli bir faktör olduğunu bildirmiştir. Muş ili süt işletmecileri içerisinde eğitim seviyesi ilkokul ve ortaokul olan yetiştiricilerin memnuniyet düzeylerinin daha yüksek olduğu tespit edilmiştir (Bakır ve Kibar, 2019a). Siirt ili besi işletmecileri içerisinde ise eğitim seviyesi ilkokul ve ortaokul olan yetiştiricilerin memnuniyet düzeyleri lise ve okuryazar olmayan yetiştiricilere göre daha düşük bulunmuştur (Bakır ve Kibar, 2019b). Siirt ilinde eğitim seviyeleri ile memnuniyet arasında bildirilen sonuç ile bu çalışmada elde edilen sonuçlara arasında farklılık bulunmuştur.
Besicilikten memnuniyet, işletmelerde yetiştirilen hayvan sayısına göre incelendiğinde, hayvan sayısı 5 ve az olan işletmelerde besicilikten memnuniyet oranı \%63.5 iken, hayvan sayısı arttıkça (21-40) memnuniyet oranı \%72.9'a yükselmiştir (Çizelge 4). Hayvan sayısı arttıkça işletmecilerin memnuniyet oranının artması, işletmelerin imkânlarının iyileşmesine, besiciliği profesyonel olarak yapan işletmecilerin sayısının artmasına ve işletmecilerin bilgi düzeylerinin yükselmesine ve besicilikten elde edilen gelirin artmasına bağlanabilir. İşletmeler arasında en yüksek (\%39.8) memnuniyetsizlik oranı 620 baş hayvana sahip işletmelerde tespit edilmesi, memnuniyet sonuçlariyla uyumlu bulunmuştur.

Siirt ilinde yapılan çalışmada (Bakır ve Kibar, 2019b) işletmelerin hayvan sayısı arttıkça işletmecilerin memnuniyet seviyelerinin azaldığı ve işi sürdürmek istemelerinde bir dalgalanma söz konusu olsa da, yine de bir azalmanin olduğu tespit edilmiştir. $\mathrm{Bu}$ bakımdan mevcut çalışma ile farklılık göstermiştir. Ancak Bakır ve Kibar (2019a)'ın Muş ilinde yaptıkları çalışmada, hayvan sayısı arttıkça memnuniyetin artması, bu çalışma ile benzerlik göstermektedir. Özen ve Oluğ (1996) çalışmasında, işletmecilerin \%85.8'inin memnun, \%14.12'sinin memnun olmadıklarını bildirmişlerdir. İşletme büyüklüğü ile memnuniyet derecesi arasında önemli $(\mathrm{p}<0.05)$ bir ilişki tespit edilmiştir. En yüksek (\%86.84) memnuniyet derecesi 6-10 baş arası hayvana sahip işletmelerde görülmüştür. 1-5 arası ve 11'den fazla baş hayvana sahip işletmelerin memnuniyet dereceleri sırasıyla $\% 85.8$ ve $\% 83.3$ olarak bulunmuştur. Mevcut çalışma ile Özen ve Oluğ (1996)'un sonuçları farklılık göstermiştir. $\mathrm{Bu}$ durum, yıllar geçtikçe az hayvan sayısı ile elde edilen gelirin yeterli olmadığı ve daha fazla hayvana ihtiyaç olduğu şeklinde yorumlanabilmektedir.

İşletmelerde yetiştirilen ırklar işletmecilerin memnuniyet düzeylerini önemli derecede etkilemiştir $(p<0.05)$. Irklar içerisinde işletmecilerin en yüksek (\%67) memnuniyet oranı melez irkında bulunurken, bunu kültür ırkı izlemiştir (Çizelge 4). İşletmelerde en fazla yetiştirilen irkın melez irk olduğu dikkate alındığında, en yüksek memnuniyetin melez rrk yetiştiren işletmelerde olması beklenen bir durumdur. Melez irkın yetiştirildiği işletmelerde memnuniyetin diğer rrkların yetiştirildiği işletmelerden yüksek bulunması dikkat çekici bulunmuştur.

Muş ilindeki sığır işletmelerinde işletmecilerin en çok memnun oldukları ırklar sirasıyla melez, kültür ve yerli şeklinde bulunmuş (Bakır ve Kibar, 2019a) ve mevcut çalışma ile benzerlik göstermektedir. 
Cizelge 4. Memnuniyetin hayvan sayısı ve yetiştirilen ırka göre değişimi

Table 4. Change of satisfaction according to the number of animals available and breed

\begin{tabular}{|c|c|c|c|c|c|c|c|c|c|c|c|c|c|}
\hline \multirow{2}{*}{\multicolumn{2}{|c|}{$\begin{array}{l}\text { Memnuniyet } \\
\text { (Satisfaction) }\end{array}$}} & \multicolumn{4}{|c|}{$\begin{array}{c}\text { Hayvan sayısı (the number of } \\
\text { animals available) }\end{array}$} & \multirow{3}{*}{$\begin{array}{r}\begin{array}{r}\text { Toplam } \\
(\text { Total) }\end{array} \\
235\end{array}$} & \multicolumn{6}{|c|}{ Mevcut irk* (Available breed) } & \multirow[b]{2}{*}{$\begin{array}{r}\text { Toplam } \\
\text { (Total) }\end{array}$} \\
\hline & & $5<$ & $6-20$ & $21-40$ & $41+$ & & Yerli & Kültür & Melez & $\begin{array}{c}\text { Melez } \\
+ \text { +Kültür }\end{array}$ & $\begin{array}{l}\text { Melez } \\
+ \text { +Yerli }\end{array}$ & $\begin{array}{c}\text { Yerli+ } \\
\text { Kültür+Melez }\end{array}$ & \\
\hline \multirow{3}{*}{$\begin{array}{l}\text { Evet } \\
\text { (Yes) }\end{array}$} & Adet & 61 & 65 & 51 & 58 & & 17 & 27 & 63 & 51 & 43 & 36 & 237 \\
\hline & $\%$ Memnuniyet & 26.0 & 27.7 & 21.7 & 24.7 & 100.0 & 7.2 & 11.4 & 26.6 & 21.5 & 18.1 & 15.2 & 100.0 \\
\hline & \% Hay. sayısı/ırk & 63.5 & 60.2 & 72.9 & 66.7 & 65.1 & 45.9 & 57.4 & 67.0 & 73.9 & 74.1 & 63.2 & 65.5 \\
\hline \multirow{3}{*}{$\begin{array}{l}\text { Hayır } \\
\text { (No) }\end{array}$} & Adet & 35 & 43 & 19 & 29 & 126 & 20 & 20 & 31 & 18 & 15 & 21 & 125 \\
\hline & $\%$ Memnuniyet & 27.8 & 34.1 & 15.1 & 23.0 & 100.0 & 16.0 & 16.0 & 24.8 & 14.4 & 12.0 & 16.8 & 100.0 \\
\hline & \% Hay. sayısı/ırk & 36.5 & 39.8 & 27.1 & 33.3 & 34.9 & 54.1 & 42.6 & 33.0 & 26.1 & 25.9 & 36.8 & 34.5 \\
\hline \multirow{3}{*}{$\begin{array}{l}\text { Toplam } \\
\text { (Total) }\end{array}$} & Adet & 96 & 108 & 70 & 87 & 361 & 37 & 47 & 94 & 69 & 58 & 57 & 362 \\
\hline & \% Memnuniyet & 26.6 & 29.9 & 19.4 & 24.1 & 100.0 & 10.2 & 13.0 & 26.0 & 19.1 & 16.0 & 15.7 & 100.0 \\
\hline & \% Hay. sayısı/ırk & 100.0 & 100.0 & 100.0 & 100.0 & 100.0 & 100.0 & 100.0 & 100.0 & 100.0 & 100.0 & 100.0 & 100.0 \\
\hline
\end{tabular}

${ }^{*} \mathrm{p}<0.05$

Çizelge 5. Memnuniyetin başka bir iş yapma ve besicilik yapma sebebine göre değişimi

Table 5. Change of satisfaction according to doing another job and the reason for fattening

\begin{tabular}{|c|c|c|c|c|c|c|c|c|c|c|}
\hline & & \multicolumn{2}{|c|}{$\begin{array}{c}\text { Başka bir iş } \\
\text { yapma } \\
\text { (another job) }\end{array}$} & \multirow[b]{2}{*}{$\begin{array}{c}\text { Toplam } \\
\text { (Total) }\end{array}$} & \multicolumn{5}{|c|}{ Besicilik yapma sebebi** (the reason for doing fattening) } & \multirow[b]{2}{*}{$\begin{array}{r}\text { Toplam } \\
\text { (Total) }\end{array}$} \\
\hline \multicolumn{2}{|c|}{$\begin{array}{l}\text { Memnuniyet } \\
\text { (Satisfaction) }\end{array}$} & $\begin{array}{l}\text { Evet } \\
\text { (Yes) }\end{array}$ & $\begin{array}{r}\text { Hayır } \\
(\mathrm{No})\end{array}$ & & $\begin{array}{c}\text { Baba } \\
\text { mesleği }\end{array}$ & Sevmek & $\begin{array}{l}\text { Başka } \\
\text { iş yok }\end{array}$ & $\begin{array}{c}\text { Baba } \\
\text { mesleği } 1+\text { sevmek }\end{array}$ & $\begin{array}{l}\text { Baba mesleği } \\
+ \text { başka iş yok }\end{array}$ & \\
\hline \multirow{3}{*}{$\begin{array}{l}\text { Evet } \\
(\text { Yes) }\end{array}$} & Adet & 87 & 141 & 228 & 100 & 42 & 41 & 20 & 31 & 234 \\
\hline & $\%$ Memnuniyet & 38.2 & 61.8 & 100 & 42.7 & 17.9 & 17.5 & 8.5 & 13.2 & 100 \\
\hline & $\%$ B. iş yapma/B. yapma sebebi & 70.7 & 62.1 & 65.1 & 69.9 & 76.4 & 47.1 & 71.4 & 64.6 & 64.8 \\
\hline \multirow{3}{*}{$\begin{array}{l}\text { Hayır } \\
\text { (No) }\end{array}$} & Adet & 36 & 86 & 122 & 43 & 13 & 46 & 8 & 17 & 127 \\
\hline & $\%$ Memnuniyet & 29.5 & 70.5 & 100 & 33.9 & 10.2 & 36.2 & 6.3 & 13.4 & 100 \\
\hline & $\%$ B. iş yapma/ B. yapma sebebi & 29.3 & 37.9 & 34.9 & 30.1 & 23.6 & 52.9 & 28.6 & 35.4 & 35.2 \\
\hline \multirow{3}{*}{$\begin{array}{l}\text { Toplam } \\
\text { (Total) }\end{array}$} & Adet & 123 & 227 & 350 & 143 & 55 & 87 & 28 & 48 & 361 \\
\hline & $\%$ Memnuniyet & 35.1 & 64.9 & 100 & 39.6 & 15.2 & 24.1 & 7.8 & 13.3 & 100 \\
\hline & $\%$ B. iş yapma/ B. yapma sebebi & 100 & 100 & 100 & 100 & 100 & 100 & 100 & 100 & 100 \\
\hline
\end{tabular}


Besiciliğin yanında başka bir iş yapan işletmecilerin \%70.7 oranıyla sadece besicilik yapanlara göre daha memnun oldukları belirlenmiştir (Çizelge 5). Besi işletmecilerinin özellikle hayvan sayısı az olan küçük aile işletmecilerinin, besiden elde edilen gelire ilaveten başka iş yaptıkları için daha mutlu olmaları anlamlı bulunmuştur. İşletmecilerin besicilik yapma nedenleri frekans değerlerine göre, baba mesleği, başka iş olmaması ve besiciliği sevmek şeklinde sıralanmaktadır. Besiciliği severek yapan işletmecilerin frekans değerleri sıralamada son sırada olmasına rağmen, besicilikten en çok memnun oldukları belirlenmiştir.

Han ve Bakır (2009) çalışmalarında işletmecilerin \%81.5'inin yapacak başka işi olmadığ hayvancllıktan memnun olduklarını bildirmişlerdir. Mevcut çalı̧̧mada ise memnun olan işletmecilerin çoğunluğu baba mesleği olduğu için memnun olduklarını bulunmuştur. Yörenin coğrafi olarak geniş meralara sahip olması nedeniyle hayvancılığa elverişli olması, insanları hayvancılığa yönlendirmiş ve hayvancılık yıllar boyunca süre gelen hem geçim kaynağ 1 hem de bir meslek olarak görülmüştür. $\mathrm{Bu}$ nedenle bu çalışmada bulunan sonuç, Han ve Bakır (2009)'ın bildirdiği sonuçtan farklılık göstermektedir.

Besi sonunda hayvanlarını eder fiyata satan işletmecilerin \%74.7'sinin besicilikten memnun oldukları belirlenmiştir. Besi sonunda hayvanlarını eder fiyata satsalar bile işletmecilerin \%25.3’nün besicilikten memnun olmadıkları bulunmuştur. Besi sonunda hayvanlarinı eder fiyata satamayan işletmecilerinde \%56.1'nin besicilikten memnun oldukları tespit edilmiştir. Besicilikten memnun olmayan işletmecilerin ise \%63.9'nun hayvanlarını eder fiyata satamadıkları belirlenmiştir. Bu durumda, hayvanlarını besi sonunda eder fiyata satan işletmecilerin çoğunluğu besicilikten memnun iken, besi sonunda eder fiyata satamayan işletmecilerin yarıya yakının da besicilikten memnun olmaları anlamlı bulunmuştur. Besi sonunda hayvanlarını tüccara satan işletmecilerin diğerlerine göre besicilikten daha memnun oldukları ve kasap veya şahıslara keserek değerlendirenlerin ise memnuniyet oranının \%58.1'de kaldığı belirlenmiş̧tir (Çizelge 6).

Bakır ve Kibar, (2019b)'ın Siirt ilinde işletmecilerin memnuniyeti ile besi hayvanlarını eder fiyata satma arasında belirttikleri ilişki ile mevcut çalışmada bulunan sonuç uyum içerisindedir. İşletmecilerin memnuniyetleri ve işletmenin sürdürülebilirliği için, bir emek ve masraf sonunda elde edilen ürünlerin eder fiyata satılması gerekmektedir.

Besicilikten memnun olan işletmecilerin tamamına yakınının (\%97.4) besiciliğe devam edeceği belirlenmiştir. Besicilikten memnun olup da tamamına yakını besiciliği devam ettirmelerine rağmen, besiciliği devam ettirmek isteyenler içinde ise işletmecilerin \%73.2'sinin besicilikten memnun oldukları belirlenmiştir. Besicilikten memnun olmayan işletmecilerin \%68.3’ünün besiciliği sürdürmek istedikleri ve besiciliği sürdürmek istemeyen işletmecilerin ise \%86.7'sinin besicilikten memnun olmadıkları belirlenmiştir. Besiciliği sürdürme nedenleri frekans değerlerine göre, başka iş yok, bana yetiyor, karlı ve sevmek şeklinde sıralanmıştır (Çizelge 7). Bu sıralanmanın aksine, besiciliği karlı bulan işletmecilerin diğer nedenlerle sürdüren işletmecilerden daha yüksek oranla memnun oldukları belirlenmiştir. Başka iş olmadığı için besiciliği sürdüren işletmecilerin en düşük oranla memnun oldukları dikkat çekici bulunmuştur. Hayvancılı̆̆ı karlı olmadığ işletmecilerin tamamının besicilikten memnun olmadıkları belirlenmiştir. Diğer yandan besicilikten memnun olmayan işletmecilerin ise \%72.5'inin besiciliği karlı bulmadıkları için sürdürmedikleri belirlenmiştir. Ayrıca, besicilikten memnun oldukları halde, zamanı olmadığı için sürdürmeyen işletmecilerin oranının ise (\%66.7) azımsanmayacak oranda bulunması dikkat çekici bulunmuştur.

Siirt ilinde işletmecilerin işi sürdürmek istemelerindeki en önemli temel nedenler hayvancılıktan elde edilen gelirin yetiyor olması ve hayvancılığın karlı görülmesi iken, sürdürmek istemeyenlerde ise hayvancılığın karlı görülmemesidir (Bakır ve Kibar, 2019b). Yapılan çalışma ile mevcut çalışma, hayvancılığı sürdürmeme nedeni bakımından benzerlik gösterirken, sürdürme nedeni bakımından farklılık göstermiştir. Diğer taraftan, bu çalışmada bulunan sonuçlar Bakır ve Kibar, (2019a)'ın Muş ilinde yaptığı çalışma ile uyum içerisindedir. Buradan yetiştiricilerin hayvancılıktan beklentilerinin bölgeden bölgeye değişiklik gösterdiği sonucu çıkarılabilmektedir. Soyak ve ark. (2007) Tekirdağ ilinde yapmış olduğu çalışmada işletme sahiplerinin \%53'ünün çocuklarının bu işle uğraşmamasını istediğini ve \%47'si ise çocuklarının süt sığırcılığını sürdürmesini istediğini bildirmişlerdir. Mevcut çalışma ile Soyak ve ark. (2007)'nin sonuçları farklılık göstermiştir. Bu durumun sorulan soruya bağlı olarak değiştiği düşünülmektedir. Yani aileler çocuklarının rahat işlerde çalışmasını istediğinden mevcut çalışmada işini sürdürmek isteyenlerin oranı daha yüksek bulunmuştur. Ayrıca besicilerin sürdürme nedenleri içerisinde başka işin olmamasının oranının yüksek olması verdiğimiz bilgiyi destekler niteliktedir. 
Çizelge 6. Memnuniyetin hayvanları eder fiyata satma ve besi sonu değerlendirme göre değişimi

Table 6. Change of satisfaction according to selling at value price and fattening end evaluation of animals

\begin{tabular}{|c|c|c|c|c|c|c|c|c|c|}
\hline \multirow{2}{*}{\multicolumn{2}{|c|}{$\begin{array}{l}\text { Memnuniyet } \\
\text { (Satisfaction) }\end{array}$}} & \multicolumn{2}{|c|}{$\begin{array}{l}\text { Eder fiyata satma** } \\
\text { (Selling at value } \\
\text { price) }\end{array}$} & \multirow[b]{2}{*}{$\begin{array}{r}\text { Toplam } \\
\text { (Total) } \\
\end{array}$} & \multicolumn{4}{|c|}{ Besi sonu değerlendirme- (Fattening end evaluation) } & \multirow[b]{2}{*}{$\begin{array}{r}\text { Toplam } \\
\text { (Total) }\end{array}$} \\
\hline & & $\begin{array}{l}\text { Evet } \\
\text { (Yes) }\end{array}$ & $\begin{array}{c}\text { Hayır } \\
(\mathrm{No})\end{array}$ & & Tüccara satma & Kasap-şahıs kesme & $\begin{array}{l}\text { Tüccar } \\
+ \text { Kasap }\end{array}$ & $\begin{array}{c}\text { Tüccar+kombi } \\
\text { ne }\end{array}$ & \\
\hline \multirow{3}{*}{$\begin{array}{l}\text { Evet } \\
\text { (Yes) }\end{array}$} & Adet & 127 & 98 & 225 & 108 & 36 & 40 & 35 & 219 \\
\hline & $\%$ Memnuniyet & 56.4 & 43.6 & 100.0 & 49.3 & 16.4 & 18.3 & 16.0 & 100.0 \\
\hline & $\%$ & 74.7 & 56.3 & 65.4 & 71.1 & 58.1 & 69.0 & 64.8 & 67.2 \\
\hline \multirow{3}{*}{$\begin{array}{l}\text { Hayır } \\
\text { (No) }\end{array}$} & Adet & 43 & 76 & 119 & 44 & 26 & 18 & 19 & 107 \\
\hline & $\%$ Memnuniyet & 36.1 & 63.9 & 100.0 & 41.1 & 24.3 & 16.8 & 17.8 & 100.0 \\
\hline & $\%$ & 25.3 & 43.7 & 34.6 & 28.9 & 41.9 & 31.0 & 35.2 & 32.8 \\
\hline \multirow{3}{*}{$\begin{array}{l}\text { Toplam } \\
\text { (Total) }\end{array}$} & Adet & 170 & 174 & 344 & 152 & 62 & 58 & 54 & 326 \\
\hline & $\%$ Memnuniyet & 49.4 & 50.6 & 100.0 & 46.6 & 19.0 & 17.8 & 16.6 & 100.0 \\
\hline & $\%$ & 100.0 & 100.0 & 100.0 & 100.0 & 100.0 & 100.0 & 100.0 & 100.0 \\
\hline
\end{tabular}

$* * \mathrm{p}<0.01$

Çizelge 7. Memnuniyetin hayvancılığı sürdürme, sürdürme nedeni ve sürdürmeme nedenine göre değişimi

Table 7. Change of satisfaction according to the reason for maintaining, maintaining and not maintaining animal husbandry

\begin{tabular}{|c|c|c|c|c|c|c|c|c|c|c|c|c|c|}
\hline \multirow{2}{*}{\multicolumn{2}{|c|}{$\begin{array}{l}\text { Memnuniyet } \\
\text { (Satisfaction) }\end{array}$}} & \multicolumn{2}{|c|}{$\begin{array}{l}{ }^{1} \text { Sürdürmeyi isteme }{ }^{* *} \\
\text { (Ask to carry on) }\end{array}$} & \multirow{3}{*}{$\begin{array}{r}\begin{array}{r}\text { Toplam } \\
\text { (Total) }\end{array} \\
238\end{array}$} & \multicolumn{4}{|c|}{${ }^{2}$ Sürdürme nedeni** (Reason for carrying) } & \multirow{2}{*}{$\begin{array}{r}\text { Toplam } \\
\text { (Total) } \\
\end{array}$} & \multicolumn{3}{|c|}{$\begin{array}{l}{ }^{3} \text { Sürdürmeme nedeni** } \\
\text { (Reason for not carrying) }\end{array}$} & \multirow{2}{*}{$\begin{array}{r}\text { Toplam } \\
(\text { Total) }\end{array}$} \\
\hline & & Evet (Yes) & Hayır (No) & & Karlı & Bana yetiyor & Başka iş yok & Sevmek & & Karlı değil & Zaman yok & Sevmiyor & \\
\hline \multirow{3}{*}{$\begin{array}{l}\text { Evet } \\
\text { (Yes) }\end{array}$} & Adet & 229 & 9 & & 66 & 51 & 69 & 27 & 213 & - & 6 & 3 & 9 \\
\hline & $\%$ Memnuniyet & 96.2 & 3.8 & 100.0 & 31.0 & 23.9 & 32.4 & 12.7 & 100.0 & - & 66.7 & 33.3 & 100.0 \\
\hline & $\% 1,2,3$ & 73.2 & 18.8 & 65.9 & 97.1 & 70.8 & 58.0 & 81.8 & 72.9 & - & 60.0 & 30.0 & 18.4 \\
\hline \multirow{3}{*}{$\begin{array}{l}\text { Hayır } \\
(\mathrm{No})\end{array}$} & Adet & 84 & 39 & 123 & 2 & 21 & 50 & 6 & 79 & 29 & 4 & 7 & 40 \\
\hline & \% Memnuniyet & 68.3 & 31.7 & 100.0 & 2.5 & 26.6 & 63.3 & 7.6 & 100.0 & 72.5 & 10.0 & 17.5 & 100.0 \\
\hline & $\% 1,2,3$ & 26.8 & 81.3 & 34.1 & 2.9 & 29.2 & 42.0 & 18.2 & 27.1 & 100.0 & 40.0 & 70.0 & 81.6 \\
\hline \multirow{3}{*}{$\begin{array}{l}\text { Toplam } \\
\text { (Total) }\end{array}$} & Adet & 313 & 48 & 361 & 68 & 72 & 119 & 33 & 292 & 29 & 10 & 10 & 49 \\
\hline & $\%$ Memnuniyet & 86.7 & 13.3 & 100.0 & 23.3 & 24.7 & 40.8 & 11.3 & 100.0 & 59.2 & 20.4 & 20.4 & 100.0 \\
\hline & $\% 1,2,3$ & 100.0 & 100.0 & 100.0 & 100.0 & 100.0 & 100.0 & 100.0 & 100.0 & 100.0 & 100.0 & 100.0 & 100.0 \\
\hline
\end{tabular}

**p<0.01, ${ }^{1}$ Sürdürmeyi isteme, ${ }^{2}$ Sürdürme nedeni, ${ }^{3}$ Sürdürmeme nedeni 
Ayrıca, Ünalan ve ark. (2015)'ı Niğde ilinde sığır, koyun ve keçi yetiştiricilerinin memnuniyet düzeylerini belirlemek amacıyla bir çalışma yapmıştır. $\mathrm{Bu}$ amaçla 95 süt sığırcılığı işletmesinde anket yapılmış ve yetiştiricilerin memnun ve memnun olmadıkları konular belirlenmiştir. Süt sığırı işletmecilerinin en çok memnun oldukları ilk $3 \mathrm{konu}$ sırasıyla yetiştirilen damızlık sığır ırkı, üyesi olunan birliğin hizmetleri ve teknik personel hizmetleri olarak tespit edilmiştir. En çok memnun olmadıkları ilk 3 konu ise sırasıyla hayvanların fiyat artışı, sütün pazar durumu ve sütün satış fiyatı olarak bulunmuştur. Mevcut çalışma ile Ünalan ve ark. (2015)'in hayvancıllğ̆ı sürdürmeme nedenleri arasındaki ilişki benzerlik göstermektedir. Yani hayvancılığı sürdürmekte en etkili faktörün kazanç olduğu düşünülmektedir. Yetiştiricilerin hayvancılıktan para kazanırsa bu işi yapmaya devam edecekleri düşünülmektedir.

Benzer diğer bir çalışmada, Özen ve Oluğ (1996) süt sığırcılığından memnun olmayan işletmecilerin nedenlerini; yem fiyatlarının çok yüksek olması, süt fiyatlarının temel girdilerdeki fiyat artışlarını yakalayamaması, et, süt ve ürünlerinin ithal edilmesi, kredi faizlerinin yüksek olması, süt yağı primleri ödemelerinin gecikmesi, süt satışı bedellerinin zamanında ödenmemesi şeklinde sıralamaktadır. Mevcut çalışma ile Özen ve Oluğ (1996)'nın sonuçları benzerlik göstermektedir. Yani hayvancılığa devam etme nedeni olarak ilk faktörün hayvancllıktan elde edilen kazanç olduğu anlaşılmaktadır. Eğer Türkiye'de sığır işletmecilerinin yaptıkları işe devam etmeleri isteniyorsa ya da yeni bireylerin bu mesleği yapmaları arzulanıyorsa ilk yapılması gereken faktörün kazanç olduğu karşımıza çıkmaktadır. Bu durumda devlet politikasının yetiştiriciyi destekler nitelikte olması gerekmektedir. Bunun için verilecek olan destek ve hibelerden ziyade üreticinin ürettiği ürünlerin eder fiyatında onlardan devlet eliyle satın alınmasının çok daha faydalı olacağ düşünülmektedir. Çünkü işletmecilerin en büyük problemi hayvanların eder fiyata satılacağ bulma konusu olmuştur. $\mathrm{Bu}$ konu çözülerek Türkiye'nin hayvancılık konusunda kendisine yeter seviyeye geleceği düşünülmektedir.

\section{SONUÇ}

Il genelinde işletmecilerin çoğunluğu besicilikten memnun iken, işletmecilerin sadece \%35'inin farklı sebeplerden dolayı besicilikten memnun olmadıkları belirlenmiştir. İşletmecilerin besicilikten memnuniyetleri, mevki, yaş, süre, yetiştirilen irk ve hayvan sayısı, hayvanların eder fiyata satılması gibi faktörlere göre değişmektedir. İşletmelerin bulunduğu mevkiler arasında memnuniyet bakımından farklılık olduğu ve bu farklılıkta mevkilerdeki işletmelerin hayvan sayısı, yetiştirilen $\mathrm{rk}$, işletmecilerin yaş ve tecrübelerinin önemli rol oynadığ Örneğin, ilçeler arasında en yüksek memnuniyetin Korkut ve Varto ilçelerinde tespit edilmesi, bunun açık bir göstergesidir. Bu ilçelerdeki işletmelerin yukarıda sayılan faktörler bakımından diğer ilçelerden önemli farklılıklar gösterdiği belirlenmiştir.

Besicilikte yaş bakımından en yüksek memnuniyet 4150 yaş aralığındaki işletmecilerde belirlenirken, 51 ve üzeri yaşa sahip işletmeciler ile 30 ve daha genç olan (ki bunlar hayvancılığa yeni başlayanlar) işletmecilerde memnuniyetin azalması dikkat çekici bulunmuştur. Genç ve yaşlı işletmecilerin besicilikten memnuniyet oranlarının düşük olması, genç işletmecilerin tecrübesizliği ve işe olan güvenlerinin yetersiz olmasından, yaşlı işletmecilerin ise besicilikten beklentilerinin karşılanmamasından kaynaklandığı düşünülmektedir. Memnuniyet ile işletmelerdeki birey sayısı arasında önemli ilişki bulunmuştur. Birey sayısı 4 ve az olan işletmecilerin en yüksek memnuniyet oranına sahip oldukları ve işletmelerde birey sayısı arttıkça memnuniyet oranının azalması anlamlı bulunmuştur. İşletmelerde birey sayısı arttıkça, kişi başına düşen hayvan sayısının azaldığı ve buna bağlı olarak da gelirinde azalmasıyla birlikte memnuniyetin azaldığı düşünülmektedir.

Besicilikten memnuniyete işletmelerde yetiştirilen hayvan sayısının önemli bir faktör olduğu belirlenmiştir. Hayvan sayısı 5 ve az olan işletmelerde besicilikten memnuniyet oranı \%63.5 iken, hayvan sayısı arttıkça memnuniyet oranı \%72.9'a yükselmiştir. $\mathrm{Bu}$ durum, işletmelerin imkânlarının iyileşmesine, besiciliği profesyonel olarak yapan işletmecilerin sayısının artmasına ve işletmecilerin bilgi düzeylerinin yükselmesine bağlanabilir. İşletmelerde yetiştirilen hayvan irkları işletmecilerin memnuniyet düzeylerini önemli derecede etkilediği belirlenmiştir. Irklar içerisinde işletmecilerin en yüksek (\%67) memnuniyet oranı melez ırk da bulunurken, bunu kültür ırkı izlemiştir. İşletmelerde memnuniyetin kültür ırklarının yetiştirildiği işletmelerde değil de melez ırklarının yetiştirildiği işletmelerde yüksek bulunması, işletmelerin çoğunluğunda melez ırkın yetiştirilmesine bağlanabilir.

Besiciliğin yanında başka bir iş yapan işletmecilerin, \%70.7 oraniyla sadece besicilik yapanlara göre daha memnun oldukları belirlenmiştir. İl genelinde işletmelerin özellikle hayvan sayısı az olan küçük aile işletmecilerinden oluştuğu göz önüne alınırsa, bu işletmecilerin büyük çoğunluğu hayvancılıktan başka 
da iş yaptıkları ve hayvancılığı geçime katkı olarak yaptıkları düşünülmektedir. İşletmecilerin besiciliği yapma sebepleri frekans değerlerine göre, baba mesleği, başka iş olmaması ve sevmek şeklinde siralanmaktadır. Besiciliği severek yapan işletmecilerin frekans değeri son sırada olmasına rağmen, besiciliği severek yapanların en çok memnun işletmeciler olduğu belirlenmiştir. Besi sonunda hayvanları eder fiyata satma işletmecilerin besicilikten memnuniyetini önemli şekilde etkilemiştir. Buna karşın, besi sonunda hayvanlarını eder fiyata satsalar bile işletmecilerin \%25.3'ünün besicilikten memnun olmadıkları bulunmuştur. $\mathrm{Bu}$ işletmecilerin elde edilen gelirin toplamda çok memnun edici bulmadıkları düşünülmektedir. Besi sonunda hayvanlarını eder fiyata satamayan işletmecilerin \%56.1'inin besicilikten memnun oldukları tespit edilmiştir. Bu işletmecilerin yapacak başka işlerinin olmadığı için besiciliğe devam etmek zorunda oldukları düşünülmektedir. Besicilikten memnun olan işletmecilerin tamamına yakınının besiciliği devam ettireceği belirlenmiştir.

Besicilikten memnun olmamalarına rağmen, \%68.3 gibi önemli bir işletmeci grubunun besiciliği sürdürmek istemeleri, besiciliği sürdürme nedenleri arasında bulunan yapacak başka işin olmaması ve elde edilen gelirin yeterli görülmesi ile açıklanmaktadır. Başka iş olmadığı için besiciliği sürdüren işletmecilerin en düşük memnuniyet oranına sahip olmaları da bunun başka bir göstergesi olarak kabul edilebilir. Ayrıca, besicilikten memnun oldukları halde, zamanı olmadığı için besiciliği sürdürmeyen işletmecilerin de olduğu tespit edilmiştir.

\section{Çıkar Çatışması Beyanı}

Makale yazarları aralarında herhangi bir çıkar çatışması olmadığını beyan ederler.

\section{Araştırmacıların Katkı Oranı Beyan Özeti}

Yazarlar makaleye eşit oranda katkı sağlamış oldukların beyan ederler.

\section{KAYNAKLAR}

Bakır G, Kibar M 2019a. Süt Sığırcılığı İşletmelerinin Memnuniyet ve Sürdürülebilirliğine Etkili Olan Faktörler: Muş İli Örneği. Türkiye Tarımsal Araştırmalar Dergisi 6(2): 123-135.

Bakır G, Kibar M 2019b. Siirt İli Besi Sığırcılığı İşletmelerinde Memnuniyet ve Sürdürülebilirliğin Belirlenmesi. International Erciyes Agriculture, Animal \& Food Sciences Conference, 24-27 April 2019, Kayseri.

Can MF, Yalçın C 2015. İnvestigation of Organizational Responsibilty an Satisfaction Level of The Cattle Producers in Turkey. Kafkas Üniv Vet Fak Derg 21(5): 711-717.

Cochran WG 1977. Sampling Techniques (3rd Edition). John Wiley\&Sons New York.https:// www. academia.edu/29684662/Cochran_1977_Sampling_ Techniques_Third_Edition.pdf.

Düzgüneş O, Kesici T, Gürbüz F 1983. İstatistik Metodları I. Ankara Üniversitesi Ziraat Fakültesi Yayınları: 861, Ders Kitabı: 229, Ankara.

Han Y 2008. Diyarbakır İli Ergani İlçesinde Besi Sığırcılığı Yapan İşletmelerin Genel Değerlendirilmesi. Yüzüncü Yıl Üniversitesi Fen Bilimleri Enstitüsü Zootekni Anabilim Dalı, Yüksek Lisans Tezi, 89 sy.

Han Y, Bakır G 2009. Özel Besi Siğırcılığı İşletmelerinde Irk Tercihleri ve Besi Uygulamaları. Atatürk Üniversitesi Ziraat Fakültesi Dergisi 40(2): 35-41.

İnci H, Karakaya E, Şengül T, Söğüt B 2014. Bingöl İlinde Kanatlı Eti Tüketiminin Yapısı. Türk Tarım ve Doğa Bilimleri Dergisi 1 (1): 17-24.

Karakaya E, İnci H 2014. Bingöl İli Merkez İlçesi Hane Halkının Kanatlı Eti Tüketim Tercihleri. UÜ. Ziraat Fakültesi Dergisi 28 (1): 53-64.

Koçyiğit R., Diler A, Yanar M Güler O, Aydın R, Avcı M 2016. Süt Sığırcılığı İşletmelerinde Hayvan Sağlığı, Veteriner Sağlık Hizmetleri ve Yetiştirici Memnuniyeti: Erzurum İli Hınıs İlçesi Örneği. Türk Tarım ve Doğa Bilimleri Dergisi 3(1): 24-32.

Koçyiğit R, Yanar M, Aydın R, Diler A, Güler O 2018. Sığırcılık İşletmelerinde Hayvan Sağlığı, Veteriner Sağllk Hizmetleri ve Yetiştirici Memnuniyeti ve Beklentileri: Erzurum İli Narman İlçesi Örneği. Kahramanmaraş Sütçü İmam Üniversitesi Tarım ve Doğa Dergisi 21(2): 203-208.

Kwadzo GTM, Dadzie F, Osei-Asare YB, Kuwornu JK 2013. Consumer Preference for Broiler Meat in Ghana: A Conjoint Analysis Approach. International Journal of Marketing Studies 5(2): 66-73.

Mohannaj R, Mahivannan L 2012. Study on Satisfaction Level and Problems Faced by Poultry Farm Owners' With Special Reference to Namakkal District, Tamilnadu. IJMIE 2(3): 1-34.

Muldano M, Thieme O 2009. Consumer Preferences for Poultry Products in Indonesia. GCP/RAS/228/GER. Working Paper No. 12.

Özen N, Oluğ HH 1996. Burdur Süt Sığırcıllğının Sorunları ve Çözüm Önerileri. Akdeniz Üniversitesi Ziraat Fakültesi Dergisi 9(1): 309-321.

Soyak A, Soysal Mi, Gürcan EK 2007. Tekirdağ İli Süt Sığırrcılığ İşletmelerinin Yapısal Özellikleri ve Bu İşletmelerdeki Siyah Alaca Süt Sığırlarının Çeşitli Morfolojik Özellikleri Üzerine Bir Araştırma. Tekirdağ Ziraat Fakültesi Dergisi 4(3): 297-305.

Tugay A, Bakır G 2009. Giresun Yöresindeki Süt Sığgrrcılığ 1 İşletmelerinin Yapısal Özellikleri. Atatürk Üniversitesi Ziraat Fakültesi Dergisi 40(1): 
37-47.

Tutkun M, Denli M, Sessiz A 2017. Diyarbakır İli Süt Sığırcılığı İşletmelerinin Yapısal Durum Analizi. Türk Tarım-Gıda Bilim ve Teknoloji Dergisi 5(5): 476-483.

Tümer E, Ağır HB, Gürler D 2018. Broiler Üretiminde Üretici Memnuniyetini Etkileyen Faktörler. Türk Tarım ve Doğa Bilimleri Dergisi 5(4): 545-550.
Ünalan A, Ceyhan A, Şekeroğlu A, Akyol E 2015. Niğde İli Sığır, Koyun ve Keçi Yetiştiricilerinin Memnuniyet Düzeylerinin Karşılaştırmalı Olarak İncelenmesi Üzerine Bir Araştırma. 9. Ulusal Zootekni Bilim Kongresi 3-5 Eylül 2015, Konya.

Yamane T 2006. Temel Örnekleme Yöntemleri. Literatür Yayıncılık, İstanbul, 528 sy. 